\title{
Sprawozdanie z I Ogólnopolskiej Studenckiej Konferencji Medycyny Paliatywnej
}

W sobotę 16 lutego 2019 roku w Centrum Medycyny Inwazyjnej Uniwersyteckiego Centrum Klinicznego w Gdańsku odbyła się I Studencka Konferencja Medycyny Paliatywnej o statusie ogólnopolskim. Była to pierwsza Ogólnopolska Konferencja o tej tematyce, kierowana do środowiska studenckiego, która odbyła się na Gdańskim Uniwersytecie Medycznym.

Wydarzenie zostało zorganizowane przez studentów zrzeszonych w Studenckim Towarzystwie Naukowym Gdańskiego Uniwersytetu Medycznego, którzy należą do kół naukowych Onkologii i Radioterapii oraz Geriatrii. W składzie Komitetu Organizacyjnego, oprócz autora Sprawozdania i Pani Małgorzaty Styczewskiej, którzy poprowadzili całość obrad, znaleźli się: Pani Dominika Milewska, Pani Karolina Moskwińska, Pani Maria Śliwska i Pan Bartosz Sobocki. Partnerami Konferencji byli: czasopismo „Palliative Medicine in Practice" wydawane przez Via Medica, Studenckie Towarzystwo Naukowe GUMed, Gdański Uniwersytet Medyczny, Polskie Towarzystwo Onkologiczne i Okręgowa Izba Lekarska w Gdańsku. Organizatorzy przygotowali dla Uczestników wydanie wszystkich streszczeń referatów przedstawianych podczas sesji prac studenckich.

Uczestnicy Konferencji mieli okazję wysłuchać licznych wykładów eksperckich. W wykładzie otwarcia Pan prof. Wojciech Leppert przedstawił referat „Perspektywy rozwoju opieki paliatywnej i wspierającej w Polsce". Prelegent podkreślił znaczenie nowej definicji opieki paliatywnej niedawno przedstawionej przez Międzynarodowe Towarzystwo Opieki Paliatywnej i Hospicyjnej (IAHPC, International Association for Hospice and Palliative Care), w której zwrócono uwagę na konieczność wczesnego wdrażania opieki paliatywnej i integracji z innymi dziedzinami medycyny, a także kwalifikowania pacjentów $z$ wszystkimi chorobami zagrażającymi życiu, u których istnieje potrzeba wdrożenia opieki paliatywnej z powodu cierpienia, które obejmuje objawy, problemy psychosocjalne i duchowe. W pierwszym wykładzie eksperckim, Pani prof. dr hab. n. med. Monika Lichodziejewska-Niemierko przedstawiła prezentacje "Terapia uporczywa i daremna", w której zarówno na podstawie rozważań teoretycznych, jak i na przykładach prezentowanych chorych, podkreśliła konieczność podejmowania decyzji etycznych pacjentów z zaawansowanymi chorobami, które będą przynosiły jak najwięcej korzyści chorym. Obydwoje prelegenci podkreślili zgodnie, że środowisko opieki paliatywnej w Polsce jest zdecydowanie przeciwne eutanazji i wspomaganemu samobójstwu. Po obydwu wykładach nastąpiła dyskusja, w której rozważano między innymi etyczne aspekty decyzji zakończenia żywienia u Terri Schiavo podjętej przez sąd, co w konsekwencji doprowadziło do zgonu pacjentki.

W sesji prac studenckich, jako pierwsza została zaprezentowana praca „Żywienie dojelitowe w warunkach domowych pacjentów z chorobą nowotworową w okresie opieki paliatywnej" autorstwa Karoliny Kaźmierczak-Siedleckiej z Katedry i Zakładu Chirurgii Onkologicznej GUMed, Jakuba Roszkowskiego z Katedry ¡ Zakładu Fizjopatologii GUMed, Jakuba Jędrzejczaka ze Studenckiego Koła Naukowego przy Zakładzie

\footnotetext{
Adres do korespondencji:

Konrad Gądek

Student V roku kierunku lekarskiego, Przewodniczący Studenckiego Koła Naukowego Onkologii i Radioterapii GUMed, Członek Zarządu Studenckiego Towarzystwa Naukowego GUMed

ul. Marii Skłodowskiej Curie 3A, 80-210 Gdańsk

e-mail: kon.gadek@gmail.com
} 

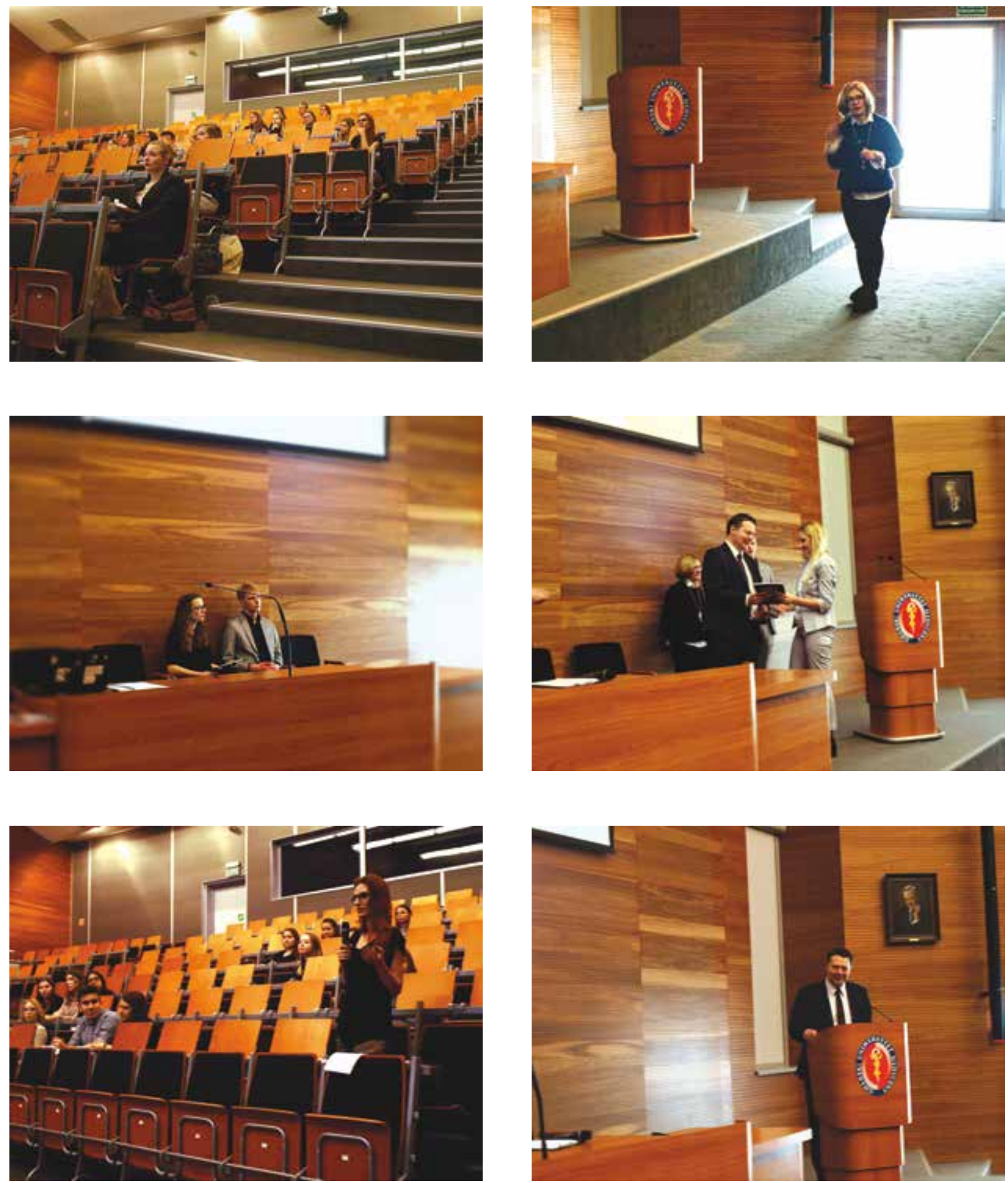

Chemii Nieorganicznej GUMed, Marcina Folwarskiego z Katedry Żywienia Klinicznego i Dietetyki GUMed, Wojciecha Makarewicza z Katedry i Zakładu Chirurgii Onkologicznej GUMed i Anny Lebiedzińskiej z Zakładu Dietetyki Państwowej Szkoły Wyższej im. Papieża Jana Pawła II w Białej Podlaskiej. Następnie zespół autorów w składzie: Justyna Kaczerska, Magdalena Kozyra, Natalia Śmiech, Krystian Cholewa, Damian Bator ze Studenckiego Koła Naukowego przy Zakładzie

Psychologii Stosowanej i Marzena Samardakiewicz z Zakładu Psychologii Stosowanej Uniwersytetu Medycznego w Lublinie przedstawił prezentację „Leczenie paliatywne raka gruczołowo - torbielowatego na świecie”. Kolejna praca zatytułowana „Fizjoterapia w wybranych problemach pacjentów znajdujących się pod opieka paliatywną" została przedstawiona przez zespól autorów: Karolina Kubiak, Martyna Lamtych, Klaudia Kwiatkowska Jakub Husejko, Paulina Trawka 
i Beniamin Szmelcer z Interdyscyplinarnego Koła Naukowego Geriatrii Collegium Medicum w Bydgoszczy. Zespól autorów: Adrian Perdyan (z Koła Naukowego przy Katedrze i Zakładzie Patomorfologii GUMed), Rafał Pęksa i Michał Bieńkowski (z Katedry i Zakładu Patomorfologii GUMed) zaprezentował pracę oryginalną: „Chemioterapia paliatywna czy pankreatektomia? - analiza pacjentów z rakiem trzustki przy pomocy kalkulatora ACS NSQIP". Praca zatytułowana „Redukcja obrzęku limfatycznego u pacjentów paliatywnych — rola kompleksowej terapii udrażniającej" została zaprezentowana przez zespól autorów: Klaudia Kwiatkowska, Karolina Kubiak, Martyna Lamtych, Jakub Husejko, Paulina Trawka i Beniamin Szmelcer.

Po przerwie, w drugim wykładzie eksperckim, Pani prof. dr hab. med. Ewa Bień przedstawiła problematykę zapewnienia jak najlepszej opieki paliatywnej najmłodszym pacjentom w wykładzie „Rola opieki paliatywnej w onkologii dziecięcej". W prezentacji podkreślono różnice opieki sprawowanej nad osobami dorosłymi i dziećmi dotyczące zarówno różnic w populacji pacjentów, jak i rodzaju schorzeń — wśród dzieci dominują głównie przewlekłe choroby nienowotworowe. Pani Profesor w przystępny sposób przedstawiła postępowanie terapeutyczne w najczęstszych objawach, posługując się interesującymi przypadkami chorych dzieci. W trzecim wykładzie eksperckim, Pani dr Justyna Janiszewska przedstawiła referat „Rola psychologa klinicznego w zintegrowanej opiece nad ciężko chorym". W prezentacji Pani doktor podkreśliła istotne znaczenie wsparcia psychosocjalnego i duchowego zapewnianego zarówno pacjentom, jak i rodzinom oraz nieformalnym opiekunom chorych.

Po przerwie obiadowej, w czwartym wykładzie eksperckim, Pani prof. dr hab. n. med. Renata Zaucha przedstawiła referat „Rola opieki paliatywnej i wspierającej w onkologii". Pani Profesor podkreśliła konieczność jednoczesnego stosowania leczenia przeciwnowotworowego wraz z postępowaniem wspierającym, które dotyczy nie tylko objawów choroby, ale także zapobiegania niekorzystnym następstwom leczenia, zwłaszcza prowadzonego z założeniem radykalnym. W prezentacji Pani Profesor przedstawiła w bardzo interesujący sposób dotychczasowe, ale również nowe kierunki leczenia nowotworów, podkreślając możliwości zastosowania zwłaszcza celowanych terapii molekularnych i immunoterapii.

Następnie wręczono nagrodę i wyróżnienia prezentowanych prac na Konferencji. Komisja Naukowa, w skład której weszli Przewodnicząca Pani prof. Monika Lichodziejewska-Niemierko, Członkowie: Pani dr Justyna Janiszewska, Pan dr Karol Wierzba i Pani dr Agata Zdun-Ryżewska, za najlepsze wystąpienie uznała wygłoszoną przez Pana Adriana Perdyana pracę oryginalną: „Chemioterapia paliatywna czy pankreatektomia? - analiza pacjentów z rakiem trzustki przy pomocy kalkulatora ACS NSQIP". Pozostałe prezentowane prace zyskały wyróżnienia.

W Konferencji wzięło udział 45 uczestników, w tym 5 wygłosiło referaty. Warty podkreślenia jest fakt, że prezentowane prace nie były autorstwa wyłącznie studentów kierunku lekarskiego — dwie z nich zostały zaprezentowane przez studentki fizjoterapii: Karolinę Kubiak i Klaudię Kwiatkowską z Collegium Medicum w Bydgoszczy. Spotkanie wyróżniało się kameralnością, pomimo dużych rozmiarów sali wykładowej. Podczas przerw wśród Uczestników Konferencji trwały dyskusje, a wystąpienia nie kończyły się bez dodatkowych pytań. Organizatorzy planują przygotowanie II Konferencji w przyszłym roku. 